\title{
Medical tourism market trends - an exploratory research
}

\author{
Florența Larisa ILE \\ The Bucharest University of Economic Studies, Bucharest, Romania \\ larisa.ile@gmail.com \\ Gabriela ȚIGU \\ The Bucharest University of Economic Studies, Bucharest, Romania
}

\begin{abstract}
Medical tourism is a modern concept, but not a new tourism practice. Even there is still no international consent on the definitions and measurement of this trend, its importance in the development of a tourism destination started to be taken into consideration. In accordance with tourism segment classification depending on journey reasons recommended by World Tourism Organization, one of the main groups is for "medical treatment/health". Being part of health tourism, medical tourism is often called medical travel because it includes the act of travelling to different countries for medical reasons. An increasing significant element in medical service trade is patient circulation at cross-border level with a view to obtaining necessary health services; this circulation generated a new phenomenon, namely medical tourism. Studying the scientific literature we find new medical tourism trends in connection with globalization and liberalization. The countries that decided to promote this niche tourism are aware of the huge economic benefits brought by this. Analyzing published data by tourism medical organizations associated to indicators of economic development, we find two aspects: the success of a medical tourism destination is influenced by the economical level of the receiving countries, but, at the same time, it is also a growth factor for developing economies if it is included in their national strategy. We intend to find the answer of several questions: trends in medical tourism development are involving only medical service trade, or a combination of specific activities of many sectors? Is the medical tourism acting in favor of developing economies? This study aims to notice the development trends of the medical tourism based on the published figures and on the experience of major destinations and to highlight the importance of the medical tourism for the developing economies.
\end{abstract}

Keywords: medical tourism, development, health, trends, developing economies, travel.

\section{Introduction}

With a millenary history, the medical tourism represents now a tourism market segment in fast developing at global level, offering a variety of aspects for the scientific research.

Starting to Sumerians which, in 4000 b. Chr., they built a place for healing around a thermal spring, visited by many travelers for its healing properties and continuing with India's Yoga and Ayurveda healing techniques attracting thousands of persons looking for health improvement, or thinking to Japan people who have travelled for over 1000 years for medical purposes to the "Onsen" mineral springs, or to pilgrims travelling to Epiduria in Greece, we are speaking about medical tourism.

Early the $16^{\text {th }}$ century, Europe became a destination for medical tourism, due to roman baths or spa. In the 1900, USA and Europe became medical centers of major interest, but only for rich persons who had the possibility to travel in order to take care of their health. In the 80's -90's travels for aesthetic surgical procedures and dentistry appeared. These tourists were attracted by medical tourism especially due to low costs, taking into consideration that in their countries these services were not covered by insurance policies. 
Today, medical tourism, despite its ancient existence, became the newest phenomena, with an accelerate development, which meets equally in very developed countries although in the developing economies.

\section{Literature review}

Considering last ten years of published articles and dedicated literature, there is not yet PICBE $\mid \mathbf{1 1 1 2}$ consistent scientific information to define, describe or prospect the facts and history of medical tourism. Most of publications are medical journals, articles, case studies, perspective of medical providers and facilitators, published presentations and results of seminars, conferences or international congresses organized by medical tourism associations. There are also several books which trait the theory of this niche tourism, but we still need more scientific contributions such as statistical, strategies and economic impact measurements.

In general, medical tourism is considered as a trip outside person's place of residence for the purpose of receiving a medical treatment, investigation or therapy, the tourists making use of destination's infrastructure, attractions and facilities (Smith and Puczko, 2014). There are various definitions of medical tourism, but the most shows that medical tourism is defined as a form of health tourism, together with wellness tourism (Stephano, 2016).

The difference between the two forms of health tourism is in the fact that medical tourism implies existence of a medical distress, that needs to be investigated, diagnosed and treated by medical procedures, being considered a reactive form of a health tourism, while wellness tourism is a proactive one (Stephano, 2016), implying preventing or maintaining health using alternative procedures, without implying specialized clinics, specialized medical personnel or invasive procedures.

At the $9^{\text {th }}$ National Health Conference having taken place in Rostock/Germany in 2013, medical tourism was defined as a branch of health and tourism industry contributing to maintaining and recovering health in general and wellness in particular, using authorized medical services. Medical tourism is not only a journey in order to improve health, but it is an economic activity implying service trade, representing a merge of at least two economic sectors: tourism and medicine (Bookman and Bookman, 2007).

Bookman and Bookman (2007) shares specific medical tourism services in the following categories: a) invasive, b) diagnostic, and c) lifestyle.

a) The most popular invasive procedure continues to be dental work due to the fact that treatment and recovery is fast, allowing to the patient "time and energy" for a vacation. In dental care and in the plastic surgery (also a popular invasive category of procedures), costs are rarely covered by the patient's insurance. The invasive procedures include now: eye surgery, cancer treatment, and joint replacements.

b) The diagnostic sector is flourishing in last decade especially for blood screening, bone density testing, heart stress tests, lipid analysis, and electrocardiograms. Progressively more, preventive health screenings are done while on vacation.

c) Services included in lifestyle medical tourism cover a broad range such as wellness, nutrition, stress reduction, weight loss, antiaging.

Beside these specific medical tourism services, this segment includes: accommodation, food and beverage, transportation, entertainment, so the competitive advantage of each destination is based on the creativity process to combine all those services with the other components of destinations (landscape, attractions, know-how, human resources, marketing etc). 


\section{Research methodology}

Starting from bibliographic documentation and published researching results of specialized publications, our work aims to provide an overview of the main approaches of the concept of medical tourism and the correlation of the quantitative researches results published, including a modern new tool, developed by the Center for PICBE|1113 International Healthcare Research, known as medical tourism Index (MTI). In this regard, we accomplish a discuss based on data collected from primary periodicals and non periodicals - traditional sources: scientific reports, papers presented at scientific events, periodicals, scientific journals, articles, newspapers, magazines, books, published between 2007 and 2017 by publishers such as Palgrave Macmillan or databases such as ProQuest LLC.

Also, our documentation is based on the expertise obtained after participating in several editions of the Medical Tourism Forum in Romania (2013-2016), as well as discussions with experts in the field, from Romania and abroad, during these events

\section{A quantitative and qualitative approach of medical tourism market}

According to the World Health Organization, medical tourism has an ongoing increasing trend, having wide economic implications. The "Patients Beyond Borders" publication estimates a market of USD 45.5-72 billion, based on approximately 7 -11 million crossborder patients, spending at global level approximately USD 3.800-6.000 per visit, including here expenses related to medical services, transportation, visas, accommodation.

There are no official statistics at global level yet and the numbers on the medical tourism market forecasts differ from one research to another.

Estimations of different associations start from $\$ 10.5$ billion in 2012 to $\$ 32$ billion in 2019 and continues his exponentially growth to $\$ 3$ trillion by 2025 .

Table 1. Estimation of the medical tourism market

\begin{tabular}{|c|c|c|}
\hline Year & Research company & Estimates \\
\hline 2016 & $\begin{array}{l}\text { Medical Tourism Association and } \\
\text { Visa report }\end{array}$ & $\$ 100$ billion and could grow to $\$ 3$ trillion by 2025 \\
\hline 2016 & Patients Beyond Borders & $\$ 38.5-\$ 55$ billion (Source unknown) \\
\hline 2015 & Patients Beyond Borders & $\$ 45-\$ 72$ billion, growing at $15-25 \%$ (Source unknown) \\
\hline 2015 & Allied Market Research & $\begin{array}{l}\text { projected CAGR growth from } 2015 \text { of } 15.7 \% \text { to } \$ 143.8 \\
\text { billion in } 2022 \text { (Proprietary source/report) }\end{array}$ \\
\hline 2014 & RNCOS & $\begin{array}{l}\text { In Asia CAGR growth of around } 22 \% \text { during } 2014 \text { to } 2018 \\
\text { (Proprietary source/report) }\end{array}$ \\
\hline 2013 & SRI International & $\$ 50-60$ billion (Source unknown) \\
\hline 2012 & Transparency Market Research & $\begin{array}{l}\$ 10.5 \text { billion, growing at CAGR of } 17.9 \% \text { to } \$ 32 \text { billion in } \\
2019 \text { (Proprietary source/report) }\end{array}$ \\
\hline
\end{tabular}
Source: Authors' own design based on Munro (2016).

A report issued by VISA and Oxford Economics (2016) project the medical tourism industry to grow up to $25 \%$ year-over-year for the next 10 years and "three to four percent of the world's population will travel internationally for healthcare and health-related treatment".

\section{Factors Influencing Medical Tourism}

The most part of specialists agrees that the rapid development of the medical tourism is influenced by factors specific to the exporting countries of medical services and by factors generating patients' interest for medical tourism, as well. 
The medical tourism constructive factors for receiving countries are: private and state investments in the infrastructure of the health system, international certification and accreditation for medical services and suppliers, the existence of an international patient flow, lower costs or better quality of medical procedures, political and social stability, excellent tourism infrastructure, good reputation about clinical excellence, proofs for the history of medical achievements, successful implementation of best practices and of newest medical technologies, highly educated medical personnel, insurance policies covering across borders (portability).

If in the first years of medical tourism research, they were identified the most important factors of demand, the recent research have to analyze them upon the segmentation of medical tourism demand. The demand is generated by medical tourists, divided by the source country, as follows (Allen, 2011):

1. Medical tourists from wealthy countries traveling for medical tourism to developing countries

2. Medical tourists from developing countries traveling for medical tourism to other developing countries

3. Medical tourists (wealthy citizens) from developing countries traveling for medical tourism to wealthy countries (reverse medical tourism)

4. Domestic medical tourism (medical tourists traveling from a city to another in the same country).

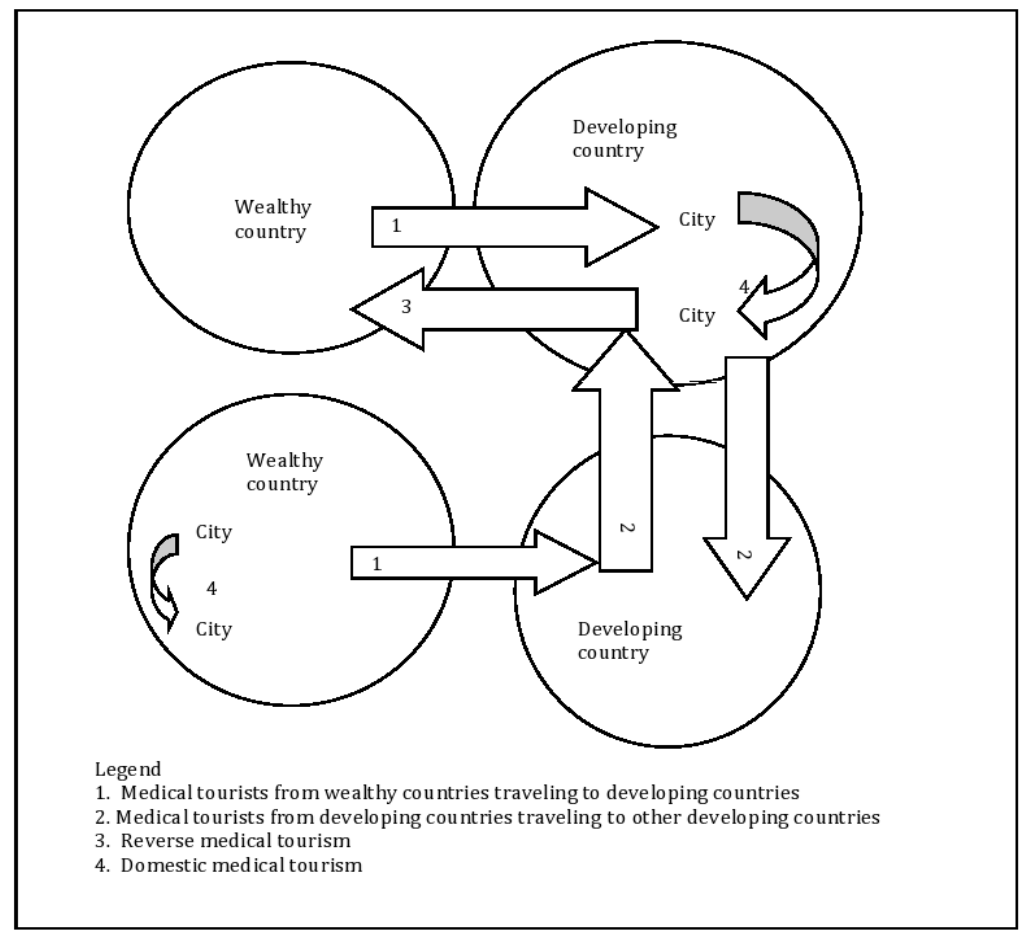

Figure 1. Segmentation of medical tourist by country of demand

Source: Authors' own design based on Allen (2011).

This segmentation is useful for a different analyze of factors generating the demand of medical tourism services.

The citizens from well developed countries are motivated to seek for medical tourism in developing countries by following reasons: the lower cost of medical services in developing countries (saving up to $30 \%$ to $85 \%$ on the medical service), the health insurances none or partial coverage, the waiting lists, availability of medical services, the possibility to combine a leisure journey with satisfying medical needs, the geographical nearness, willingness to travel and tourism culture. 
The demand of developing countries citizens is determined in principal by: the good level of quality of care, high level of medical technology and equipments, proficiency of medical staff, specialization in medical procedures or excellent medical infrastructure.

Additionally, there are global factors applicable for both segments: the transport liberalization and the development of low cost airlines, the medical or tourist visa policy, medical certification and accreditation, the global aging. (by 2025, travelers aged 65+ will more than double their international travel to 180 million trips), the increasing of personal income and the development of credit payments, the propensity for raising the travel spends.

According to Visa projection of travel spend by household earning for 2025, it is noticeable the tendency of the increase of international travel spending.

Table 2. Projection of travel spend by household earning

\begin{tabular}{|c|l|l|l|l|}
\hline \multicolumn{5}{|c|}{ Top 10 countries in travel spend } \\
\hline Rank & Country & $\begin{array}{l}2015 \\
\text { USD billion }\end{array}$ & $\begin{array}{l}2025 \\
\text { USD billion }\end{array}$ & $\begin{array}{l}\text { Percent } \\
\text { Increase }\end{array}$ \\
\hline 1 & China & 137.0 & 255.4 & $86 \%$ \\
\hline 2 & USA & 101.0 & 134.1 & $33 \%$ \\
\hline 3 & Germany & 74.4 & 97.6 & $31 \%$ \\
\hline 4 & UK & 61.3 & 96.9 & $58 \%$ \\
\hline 5 & $\begin{array}{l}\text { Russian } \\
\text { Federation }\end{array}$ & 22.6 & 49.1 & $118 \%$ \\
\hline 6 & $\begin{array}{l}\text { Hong Kong, } \\
\text { China }\end{array}$ & 26.7 & 47.4 & $48 \%$ \\
\hline 7 & Singapore & 22.5 & 44.9 & $99 \%$ \\
\hline 8 & France & 37.4 & 47.9 & $17 \%$ \\
\hline 9 & Brazil & 18.3 & 37.8 & $106 \%$ \\
\hline 10 & South Korea & 21.1 & 34.3 & $63 \%$ \\
\hline
\end{tabular}

Source: Visa: Mapping the Future of Global Travel and Tourism (2016).

This study may help medical tourism destination to adapt their strategies in order to adjust their offer to the particularities of potential demand.

With a projection of $\$ 255.4$ USD billion, China turns into the future first medical tourist demanding country. According to statistics from the Shanghai Medical Tourism Products and Promotion Platform, each year approximately 60,000 Chinese travel abroad in search of medical services ranging from anti-aging therapy, cancer screening and treatment, giving birth and chronic disease treatment. A report by Hurun and ILTM Asia indicate that 66 percent of China's 1.18 million wealthy millionaires would consider medical tourism.

\section{Tendencies of demand for medical tourism}

Considering Bookman and Bookman (2007) there are other factors for medical tourism demand taking into consideration:

Cultural Affinity. Patients from the diaspora visiting friends and family often complete their trip with health services. Also, no barrier language and the same religion are factors in determining cultural affinity. Some international patients feel cultural affinity for a region even if they not belong to the region and do not speak the language because they have traveled to there in the past and like the people, the traditions and the local culture.

Distance. The nearness is very important as geographical characteristics. In the last time, the tendency to visit medical destinations that are geographically close to the tourists' home began to be exceeded due the low air fares. 
Specialization. For some medical treatments, there are specialties that are not available elsewhere.

Reputation. Concerning problems that may arise when traveling abroad for medical care (unsuccessful procedures, infections, malpractice, etc), patients will choose those countries that have the best reputations.

The Medical Tourism Association's (MTA) reveals several changes in medical tourism demand factors.

Table 3. Changes in medical tourism demand factors

\begin{tabular}{|c|c|c|}
\hline Demand factor & 2015 & 2013 \\
\hline cost savings & $\begin{array}{l}61 \% \\
\$ 4,900 \text { and } \\
\$ 8,600 \text { USD cost } \\
\text { savings to } \\
\text { pursue medical } \\
\text { tourism. }\end{array}$ & $\begin{array}{l}80 \% \\
\text { the cost of medical treatment } \\
\text { and state-of-the-art technology } \\
\text { were the most important } \\
\text { factors in their decision to } \\
\text { travel abroad for treatment. }\end{array}$ \\
\hline quality & $21 \%$ & - \\
\hline safety & $\begin{array}{l}\text { is the most } \\
\text { important } \\
\text { factor in } \\
\text { choosing a } \\
\text { medical tourism } \\
\text { destination. }\end{array}$ & - \\
\hline $\begin{array}{l}\text { spending on medical } \\
\text { treatments per medical } \\
\text { travel trip. }\end{array}$ & $\begin{array}{l}\text { between } \$ 3,600 \\
\text { and } \$ 7,600 \text { USD }\end{array}$ & between $\$ 7,475$ and $\$ 15,833$ \\
\hline air travel & $\begin{array}{l}\text { cost less than } \\
\$ 1,000 \\
\text { USD }(57 \%)\end{array}$ & - \\
\hline insurance & $\begin{array}{l}65 \% \text { of patients } \\
\text { participating in } \\
\text { medical travel } \\
\text { are not covered }\end{array}$ & $\begin{array}{l}64 \% \text { did not have health } \\
\text { insurance (2009 survey) }\end{array}$ \\
\hline
\end{tabular}

Source: Authors' own design based on www.medicaltourismassociation.com.

The most important identified changes are: the advent of quality and safety as the most important factor in choosing a medical tourism destination; the cost of medical procedure is loosing its first rank, the medical treatments spending per medical travel trip decreased with 50\% in just two years; a new entry is the air travel cost due to the low cost airlines; the insurance cover is keeping the same percent of medical tourists, new medical travel insurance products have begun to appear but still need time to develop.

\section{Trends in medical tourism destinations}

In 1997, within the United Nations Conference for Trade and Development (UNCTAD) it is mentioned for the first time that for the developing countries, service trade, including medical service trade, can be advantageous. These countries feature labor force, invested capital, knowhow and offer incentives for medical tourism (Bookman and Bookman, 2007). The most famous developing countries branded as destinations for medical tourism are: India, Thailand, Singapore, Malaysia, Philippine, Cuba, Costa Rica, Argentina, South Africa, Jordan, Turkey, where we can add Eastern Europe countries (Hungary, Poland, Romania) and their number continues to increase, every year. 
To analyze the medical tourism destination trends, there is a new modern instrument developed by the International Healthcare Research Center, known as Medical Tourism Index (MTI). The MTI results are based on a U.S. representative sample of 3,000 people in respect to 6-demographic dimensions. Definition of Medical Tourism Index (www.medicaltourismindex.com) specifies that it measures the "attractiveness of a country as a medical tourism destination in terms of overall country image and environment; healthcare and tourism attractiveness and infrastructure; and availability and quality of medical facilities and services". The destination selection consist of three criteria: the most important - destination as identified in the popular press and the literature; a global survey with 4,000 prospective medical tourism patients and 394 members from the Medical Tourism Association (MTA) asked which countries are the most important for Medical Tourism and third, a balanced geographical distribution. The 2016 MTI considers 41 destinations from the Middle East, Asia, Americas, Africa, and Europe.

Analyzing 2015 and 2016 reports, it reveals changes in the top five medical tourism destinations by overall MTI ranking: India is rising and takes the $5^{\text {th }}$ place and Costa Rica down on $14^{\text {th }}$ rank.

Table 4. MTI 2016 medical tourism destinations

\begin{tabular}{|c|l|l|l|l|}
\hline Rank & \multicolumn{2}{|c|}{$\begin{array}{c}\text { Medical Tourism Index } \\
\text { 2016 overall rank }\end{array}$} & \multicolumn{2}{c|}{$\begin{array}{c}\text { Medical Tourism Index } \\
\text { 2015 overall rank }\end{array}$} \\
\hline $\mathbf{1}$ & Canada & 76,62 & Canada & 76,87 \\
\hline $\mathbf{2}$ & UK & 74,87 & UK & 74,85 \\
\hline $\mathbf{3}$ & Israel & 73,91 & Israel & 74,17 \\
\hline $\mathbf{4}$ & Singapore & 73,56 & Singapore & 73,96 \\
\hline $\mathbf{5}$ & India & 72,10 & Costa Rica & 72,78 \\
\hline
\end{tabular}

Source: Authors' own design based on www.medicaltourismindex.com.

Table 5. Subindex of MTI TM 2016

\begin{tabular}{|c|c|c|c|c|}
\hline Country & $\begin{array}{c}\text { Destination } \\
\text { environment } \\
\text { index }\end{array}$ & $\begin{array}{c}\text { Medical } \\
\text { Tourism } \\
\text { industry } \\
\text { index } \\
\text { Rank }\end{array}$ & $\begin{array}{c}\text { Quality of } \\
\text { facilities \& } \\
\text { services index } \\
\text { Rank }\end{array}$ \\
\hline $\mathbf{1}$ & Canada & 1 & 4 & 4 \\
\hline $\mathbf{2}$ & UK & 2 & 17 & 5 \\
\hline $\mathbf{3}$ & Israel & 4 & 11 & 1 \\
\hline $\mathbf{4}$ & Singapore & 3 & 15 & 6 \\
\hline $\mathbf{5}$ & India & 12 & 1 & 3 \\
\hline
\end{tabular}

Source: Authors' own design based on www.medicaltourismindex.com.

Table 6. Subindex of MTI TM 2015

\begin{tabular}{|l|l|l|l|l|l|}
\hline & & $\begin{array}{l}\text { Country } \\
\text { Environ- } \\
\text { ment }\end{array}$ & $\begin{array}{l}\text { Desti- } \\
\text { nation } \\
\text { Attrac- } \\
\text { tive-ness }\end{array}$ & $\begin{array}{l}\text { Medical } \\
\text { Tourism } \\
\text { Costs }\end{array}$ & $\begin{array}{l}\text { Quality of } \\
\text { facilities \& } \\
\text { services }\end{array}$ \\
\hline $\mathbf{1}$ & Canada & Canada & $\begin{array}{l}\text { Costa } \\
\text { Rica }\end{array}$ & Canada & Israel \\
\hline $\mathbf{2}$ & UK & UK & Israel & Costa Rica & Singapore \\
\hline $\mathbf{3}$ & Israel & Israel & Jamaica & India & Germany \\
\hline $\mathbf{4}$ & Singapore & Singapore & France & Philippines & India \\
\hline $\mathbf{5}$ & Costa Rica & Germany & Italy & Colombia & Canada \\
\hline
\end{tabular}

Source: Authors' own design based on www.medicaltourismindex.com. 
Canada was ranked $1^{\text {st }}$ both years, because it is a wealthy, democratic and developed nation with a solid government that does not allow corruption, as is specified in the MTI country profile. Considering the medical tourism factor, Canada is first ranked as medical tourism costs in 2015 , and in 2016 it is on the $4^{\text {th }}$ place on the medical tourism industry and the same place considering the quality of medical facilities \& services.

$U K$ is ranked the second medical tourism destination in the world. The UK is known as a cultural destination and one of the world's more globalized economies. UK is maintains its tourism medical destination second position in the last two years, based primary on the country and destination environment sub - indexes.

Israel is the $3^{\text {rd }}$ medical tourism destination ranked on MTI 2016. The country has a technologically advanced market economy being the $67^{\text {th }}$ largest economy in the world. Tourism is one of its major sources of income, and an economic growth engine. The destination is described on the MTI country profile as one of the most technologically advanced healthcare systems in the world, with highly equipped modern facilities. This could be noticed on the 2015 and 2016 sub-index "Quality of facilities \& services" where Israel maintains its first position. Israel changes the $3^{\text {rd }}$ position of the "Country environment" 2015 sub-index, to the $4^{\text {th }}$ place on the 2016 "Destination environment" for Singapore.

Singapore is a multicultural population with economy ranked the $36^{\text {th }}$ in the world by nominal GDP. Tourism is a major industry and a great contributor to the economy. The MTI profile country consider Singapore an environmentally friendly nation, tourists can enjoy a safe city with English as the most spoken language out of the 4 official ones. Singapore go up one step from the $4^{\text {th }}$ place of 2015 sub index "Country Environment" to the 3rd position of the 2016 sub-index "Destination environment".

Costa Rica is ranked on $5^{\text {th }}$ position on MTI 2015. Costa Rica - a prime destination for the medical traveler is well known for ecotourism and the relative political tranquility. Costa Rica was named the country most recommended tourism destination in the world by the Global Tourism Monitor Survey (based on 23,000 globetrotters from 26 countries where they had traveled during the previous 12 months). In the 2015 MTI ranking of sub-dimensions, Costa Rica is on the first place in the Score Destination Attractiveness and the second on Medical Tourism Costs sub-index.

In 2016, the Costa Rica's $5^{\text {th }}$ place is taken by India. The most frequent medical tourists for India are Americans, Canadians, and Europeans seeking treatment at very low costs. In the $2016 \mathrm{MTI}$ overall ranking, India is taking the $5^{\text {th }}$ place, being on the first place concerning the medical tourism industry in 2016, as against the $3^{\text {rd }}$ place in 2015. As quality of facilities and services, India is the $3^{\text {rd }}$ destination in 2016, upping one place, from the $4^{\text {th }}$ position in 2015, but as destination environment India it is not among the top five MTI. According to the Global Tourism Monitor Survey, India is on the $60^{\text {th }}$ place amongst the 65 destinations as tourism destination. Analyzing the MTI in the last two years, India records the most spectacular development as medical tourism destination.

Considering the MTI report and analyzing the changes occurred in the last year, we have to consider the medical tourism industry development as an opportunity and a driven factor for the growth of the entire tourism destination, particularly regarding developing countries. 


\section{Medical tourism and sustainability}

The United Nations General Assembly declared 2017 as the International Year of Sustainable Tourism for Development.

As a growing industry, the medical tourism has to adapt its development strategies, procedures and activities to environmental sustainability.

World Tourism Organization says sustainable tourism is applicable to all forms of PICBE | 1119 tourism and all types of destinations, including mass tourism and the various niche tourism segments.

Medical tourism influences, with positive and negative impacts on the sustainability of economy, social and environment.

As economic positive influences, medical tourism generates rising incomes (exports), investments in modern equipment and technology conducting to less pollution, saving energy and protection of natural resources (in many situations the prime factor for the medical recovery or rehabilitation in medical tourism).

Cultural and social positive impact focus on inter cultural changes, tolerance or preservation of local authenticity. Generating new possibilities of employment, the medical tourism offer the opportunity of getting back home the brains emigrated years ago in west developed countries. Oriented to research and permanent education, medical tourism develops the entire society in the spirit of acceptance, peace and openmindedness.

The use of environmental resources is part of most medical tourism procedures (mineral and thermal water, therapeutically caves, gas and mud, microclimate, sand, forests, rivers and lakes, etc). Protecting the ecosystems and biodiversity by rules and policies, the medical tourism stakeholders guarantee the durability of development.

The negative impacts consist in discrepancies accentuation between locals and foreign medical tourists in terms of quality and affordability of medical services. Also, the allocation of medical resources for foreign patients can increase care costs for local patients due to increased demand or, the medical tourism encourage the relocation of health employees from the public to the private sector.

\section{Conclusions}

Medical tourism is an opportunity for developing countries that should take advantage of the favorable international context and invest in creating and promoting a competitive medical touristic offer. We found that the growth of a medical tourism destination is influenced by the superior economical level of the receiving countries, but, at the same time, it is also a growth factor for developing economies if it is included in their national strategy. Trends in medical tourism development are involving the medical service trade but also a combination of specific activities of many sectors: travel, hospitality, safety, health system, government strategies, destination management and marketing, education, research, sustainability, etc. The international accreditation and certification turn into a very important factor in developing the medical tourism.

The medical tourism industry has become more structured, based on quality and safety of medical services and suppliers, in the meantime, being a social, cultural and economic phenomenon that generates impacts relating to the sustainable environment.

The article provides information about trends in ranking of medical tourism destinations and evidences the changes in the last two years of top five positions. Factors influencing the medical tourism demand vary depending on the typology of the sender country (developed and developing countries), differentiated by motivations and requirements. Future research could be paying attention on analyzing the medical 
tourism in developing country, as trigger for the augmentation of tourism destination awareness.

\section{References}

Allen K; (2011). The making of medical subjects: medical tourism and its adherence to neoliberal ideologies, ProQuest LLC.

Guy, B. S., Henson, J. L. N., \& Dotson, M. J. (2015). Characteristics of consumers likely and unlikely to participate in medical tourism. International Journal of Healthcare Management, 8(2), 68-76.

Bookman M., Bookman, K. (2007). Medical tourism in developing countries, Palgrave Macmillan, New York.

Castro Lotero A, (2013). Medical Tourism Sustainable Development, Medical Tourism Magazine November 21, 2013 available at http://www.medicaltourismmag.com.

Chanda R; (2001). Trade in health services, Working Paper, No. 70, Indian Council for Research on International Economic Relations, New Delhi, India, November 2001.

Horowitz, M. D., Rosensweig, J. A., \& Jones, C. A. (2007). Medical tourism: globalization of the healthcare marketplace. Medscape General Medicine, 9(4), 33.

Ile, F.L. (2016). Medical tourism market - trends in the context of globalization, in Emerging Markets Economics and Business; Contributions of Young Researchers; Proceedings of the 7th Conference of Doctoral Students in Economic Sciences, University of Oradea, Faculty of Economic Sciences, No. 4 December 2016.

Iordache, C., Ciochina, I., \& Popa, R. (2013). Turismul medical-între continut si deziderat în dezvoltarea economico-sociala. Strategii de dezvoltare/Medical tourismbetween the content and socio-economic development goals. Development strategies. Romanian Journal of Marketing, (1), 18.

Lunt N, et al., (2011). Medical tourism: treatments, markets and health system implications: a scoping review. Organization for Economic Co-operation and Development; 2011. Available on: http://bit.ly/1Fuf1NH [accessed November $15,2016]$.

Munro, J. (2016). How Big is the Medical Tourism Industry? [Online], Available on https://www.mtqua.org/ (accessed September 27, 2016).

Smith M., Puczko L., (2014). Health, Tourism and Hospitality. Spas, Wellness and Medical Travel, Routledge, London and New York.

Snyder J., Crooks, A.V., Turner, L., Johnston, R. (2013). Understanding the impacts of medical tourism on health human resources in Barbados: a prospective, qualitative study of stakeholder perceptions, International Journal for Equity in Health. 2013;12: 2. Retrieved from www.ncbi.nlm.nih.gov (accessed February $8,2017)$.

Woodman, W. (2016). Medical Tourism Statistics \& Facts [online] available on www.patientsbeyondborders.com (accessed November 18, 2016).

Tompkins, Olga (2010). "Medical Tourism". AAOHN Journal. 58 (1): 40. doi:10.3928/08910162-20091223-04.

Horowitz, M.D., Rosensweig, Jeffrey A., Jones, C.A. (2007). Medical Tourism: Globalization of the Healthcare Marketplace. Medscape General Medicine 9 (4): 33. PMC 2234298 Freely accessible. PMID 18311383.

Dyer, Z. (2014, June 11). Costa Rica named top tourism destination in new global survey Retrieved from www.ticotimes.net (accessed February 8, 2017). 
Visa. (2017).Mapping the Future of Global Travel and Tourism, Retrieved from www.usa.visa.com/dam/VCOM/global/partner-with-us/documents/globaltravel-and-tourism-insights-by-visa.pdf (accessed January 29 2017).

Treatment Abroad - Health and Medical Tourism, A guide to medical travel insurance Retrieved on www.treatmentabroad.com/services/medical-travel-insurance (accessed February 7, 2017).

Transparency Market Research (2013). Medical Tourism Market (India, Thailand, Singapore, Malaysia, Mexico, Brazil, Taiwan, Turkey, South Korea, Costa Rica, Poland, Dubai and Philippines) - Global Industry Analysis, Size, Share, Growth, Trends and Forecast, 2013 - 2019, Retrieved from http://www.mrrse.com/medical-tourism/preview-analysis, (accessed December $28,2016)$.

UN World Tourism Organization, UNWTO Tourism Barometer, January 2016, Vol. 14. Retrived from http://mkt.unwto.org/barometer (accessed February, 2017).

UNEP and UNWTO (2005) Making Tourism More Sustainable - A Guide for Policy Makers, p.11-12. Retrived from www.sdt.unwto.org (accessed February, 2017). 